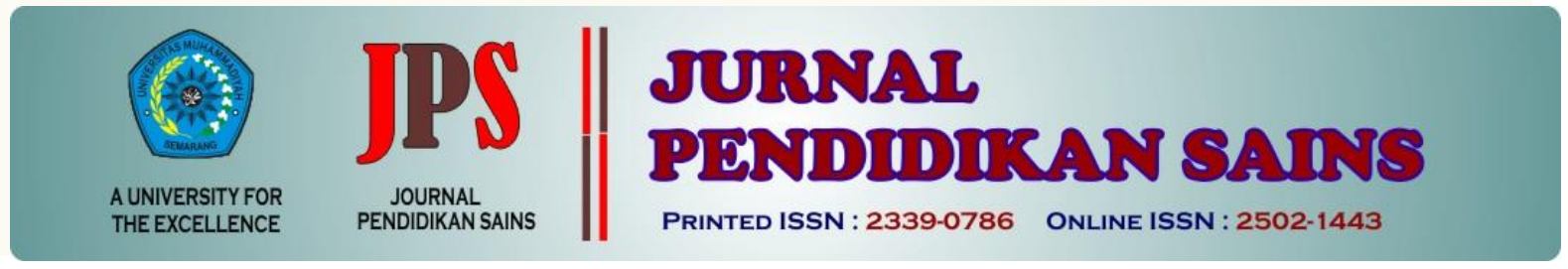

http://jurnal.unimus.ac.id/index.php/JPKIMIA

\title{
ENHANCING OF PRESERVICE CHEMISTRY TEACHERS' SELF-EFFICACY THROUGH THE PREPARATION OF PEDAGOGICAL CONTENT KNOWLEDGE IN VOCATIONAL CONTEXT
}

\author{
Antuni Wiyarsi \\ Chemistry Education Department, Faculty of Mathematics and Science \\ Universitas Negeri Yogyakarta
}

\begin{tabular}{|c|c|}
\hline Article history & Abstract \\
\hline Submission : $2018-02-20$ & \multirow{5}{*}{$\begin{array}{l}\text { Pedagogical Content Knowledge (PCK) development of } \\
\text { appropriate chemistry in vocational context is necessary to prepare the } \\
\text { capability of pre-service chemistry teachers in designing effective } \\
\text { chemistry learning in vocational schools. This study aims to assess the } \\
\text { self-efficacy pre-service chemistry teachers by the learning based on } \\
\text { PCK development in vocational context. Pretest-posttest control group } \\
\text { design was used in these research. The results showed that the PCK } \\
\text { development strategy in the vocational context is able to increase self- } \\
\text { efficacy of pre-service chemistry teachers. Most of pre-service } \\
\text { chemistry teachers have increased self-efficacy, although some of pre- } \\
\text { service teachers have decreased self-efficacy. The main implication of } \\
\text { this research is the need for restructuring of the curriculum for pre- } \\
\text { service chemistry teacher education programs that are more concerned } \\
\text { with professional development in the context of vocational schools. }\end{array}$} \\
\hline Revised & \\
\hline : 2018-03-08 & \\
\hline Keyword: & \\
\hline $\begin{array}{l}\text { Chemistry in vocational } \\
\text { context, PCK, Pre-service } \\
\text { chemistry teacher, Self } \\
\text { efficacy }\end{array}$ & \\
\hline
\end{tabular}

\section{Introduction}

Professional development should be inculcated since the chemistry teachers take on the education. The comprehensive training and habituation when take on education would be a good start for pre service chemistry teachers to become professional teachers in the future. Likewise for pre service chemistry teachers who would teach in vocational schools. Professional development of preservice chemistry teachers affected by many factors. There are both external and internal factors within themselves. One of the internal factors that play a role in bringing about the necessary competence to become a chemistry teacher at a vocational school professional is the ability of pre service teachers to recognize their own abilities in teaching chemistry at a vocational school effectively. It means associated with the confidence of pre-service teachers to be able to achieve what they wanted.

Bandura's social cognitive theory provides a framework for examining one's confidence in a concept called self-efficacy. Bandura defined self-efficacy as the belief about one's own capabilities to organize and execute a certain task (Bandura, 1997: 21-22). Self-efficacy is not directly related to the skills of the individual, but about the self-assessment of what can be done, without relating to the skills possessed. Meanwhile, Zimmerman (2000:84)

*Corresponding Author:

$\begin{array}{ll}\text { Nama } & \text { : Antuni Wiyarsi } \\ \text { Lembaga } & \text { : Universitas Negeri Yogyakarta } \\ \text { Email } & \text { : antuni_w@uny.ac.id }\end{array}$


states that self-efficacy is a personal assessment of his ability to organize and implement the work program in achieving its intended purpose, and he tried to assess the level, generality and strength of all the activities and context. Thus, self-efficacy is a matter of subjective perception related to the belief belong to individual, showing how the one's confidence to carry out certain tasks. It exists in many domains of human functioning, including both professional and private behaviour.

In particular, in the context of education, self-efficacy of teachers is described as a teacher confidence in its capacity to plan learning and achieve learning objectives (Gavora, 2010: 20). It is in effect the conviction the teacher has about his/her ability to teach pupils efficiently and effectively. According to Bandura's theory, self-efficacy has two components: efficacy expectational and outcome expectancy. The first is the conviction that one has the ability, knowledge, and skills to successfully execute the behavior or actions required to produce the desired outcomes. The second represents a person's estimate of the likely consequences (impact) of performing a task at the self-expected level of performance. That is, outcome expectancy is the belief that a given behavior or action will indeed lead to expected outcomes.

Self-efficacy of teachers is one of the personal characteristics of teachers are correlated with student achievement (Woolfolk, 2008: 219). Teachers' belief that they are able to overcome the problem of learning and help students to improve learning ability is positively correlated with an increase in the teachers' ability to apply their knowledge and teaching skills, while low of teachers' belief will hamper developing of professionalism teachers (Gavora, 2010: 21).Teachers with high self-efficacy level of have been shown to be more resilient in their teaching and likely to try harder to help all students to reach their potential. In contrast, teachers with a low level of teacher self-efficacy have been found to be less likely to try harder to reach the learning needs of all their students. It be the principal reason that the investigation of the self-efficacy development of pre service teacher in their education is important.

According to Bandura (1997: 80-87), people's self-efficacy can be developed through four main sources of influence or information: mastery experiences, vicarious experiences, social persuasion, and physiological responses. Meanwhile, the result of science education research previously reveals that various factors associated with both method of science learning and science content contribute to science teaching self-efficacy (Bleicher \& Lindgren, 2005; Cantrell, Young, \& Moore, 2003; Palmer, 2006; Schoon \& Boone, 1998). Science methods courses have a positive impact on selfefficacy for teaching, especially when the program takes into account the four main influences on self-efficacy (Cantrell et al., 2003; Settlage, 2000). Other studies have demonstrated the importance of subject matter, or a good understanding of science, for science teaching self-efficacy (Rohaan et.al., 2012; Schoon \& Boone, 1998; Yilmaz-Tozun. \& Tupzun, 2008), which implies the value of science content learning for increasing science teaching self-efficacy.

Previous studies shown that self-efficacy development is influenced by the experience of learning. So, preservice teacher education programs play an important role in the development of beginning self-efficacy and identity of a teacher. Education for pre service chemistry teachers must provide as much opportunity as possible for them for mastering the knowledge and skills needed. Similarly, to gained self-efficacy of pre service chemistry teacher to teach at vocational schools, pre service chemistry teacher education should facilitate experience and mastery of specific content in vocational context.

Differences in the characteristics of general education and vocational education which includes the characteristics of the chemistry content that is taught, chemistry learning objectives and characteristics of vocational and general education programs implication on the need for preparation of specific capabilities for pre service chemistry teachers (Finch \& Crunkilton, J.R. 1984; Khasawneh er.al., 2008, Faraday et.al., 2011; Dolfing et.al., 2011). Meanwhile, according to Faraday et.al. (2011), learning in vocational education is basically no different from the sphere of education, except in one aspect, namely context. This context is the integration of the nature of vocational subject, the circumstances in which learning takes place, purpose and desired outcomes that are appropriate to the specifications of vocational qualifications, the nature of the student and how the student's learning style. 
Learning aspects of the specific content, the appropriate context in which the content is taught is very important for pre service chemistry teachers, because most teachers have limitations in transferring content due to low of their concept mastering (Kapyla et.al., 2009; Magnusson et.al., 1999). In addition, the chemistry pre service teachers should have pedagogical knowledge that can be implemented correctly at the specific chemical contents. Shulman (1986: 6-7) introduces it as a Pedagogical Content Knowledge (PCK) to develop professionalism by introducing new forms of teacher knowledge that integrates the content and pedagogical knowledge. PCK that specific in vocational context is a new specific knowledge is needed by pre service chemistry teachers to prepare themselves to become a professional teacher in a vocational school.

Pedagogical knowledge refers to the 'broad principles and strategies of classroom management and organization that appear to transcend subject matter' (Shulman, 1986: 6-7). PCK is an amalgamation of content and pedagogy in a specific context (Gess-Newsome, 1999: 84-85). In other words, it refers to knowledge about teaching and learning of particular subject matter that takes into account the particular learning demands inherent in the subject matter (Bucat, 2004). PCK as a construct of teachers' knowledge is subject and domain-specific (Shulman, 1986; Shulman, 1987, Bucat, 2004). This knowledge consists of seven categories. Three category related to the content and the four associated with general pedagogy, students and their characteristics, the context of education and educational purposes. Meanwhile, according to Magnusson, Krajcik and Borko (1999: 103-105), the component of PCK include orientation of teaching science (related to the subject matter), knowledge of the science curriculum, knowledge of learning strategies, knowledge of assessment and knowledge about the students' understanding of science. So, while learning "how" to teach chemistry, teachers should develop sound knowledge of chemistry concepts and principles, as well as appropriate strategies for specific chemistry topics and where the topics be taught.

Loughran et al (2006) developed a model representation of PCK a teacher in two forms of documents, namelyContent Representation (CoRe) dan Pedagogical and Professional experience Repertoires (PaP-eRs). Both of documents make explicit the different dimensions of, and links between, knowledge of content, teaching, and learning about a particular topic. The CoRes attempt to portray holistic overviews of expert teachers' PCK related to the teaching of a particular topic. They contain a set of enduring ideasabout a particular topic at the head of the columns and a set of pedagogical questions for each row. PaPeRs is a narrative that describes how the content is presented.

CoRe have been used successfully in preservice science teacher education to help novice teachers understand what PCK might involve and to develop their own representations of teaching in particular topic areas. In the study by Loughran, Mulhall and Berry (2008: 1306), a pre-service educator invited student teachers to construct their own examples of CoRes after they had examined and reflected on those created by expert teachers. The findings from study of Loughran et al. strongly suggest that the focus on PCK using CoRe to frame their thinking about the links between science content and pedagogy did help the student teachers to gain a more sophisticated view about learning to teach science and how to teach for understanding. Another study along similar lines also sought to promote science student teachers' PCK through CoRe design (Hume \& Berry, 2011: 189). The results showed that the training of constructing CoRe that followed by proper scaffolding allows the development of PCK for novice teachers The pre-service teachers found the task challenging, and their lack of classroom experience and experimentation proved to be a limiting factor in being able to develop CoRe successfully.

Differences in the nature of chemistry and purpose of learning in vocational education and general education shows the need for teaching skills that appropriate to the context of vocational. It has implications for the need for the development of learning to prepare the ability of pre-service chemistry teachers in designing learning chemistry in accordance with the context of vocational. Development of the ability to design learning can be preceded by ability to draw up specific PCK in vocational context. The good basic in knowledge and skill in designing learning in vocational schools will increase self-efficacy of pre-service chemistry teachers.

Learning to develop specific PCK in vocational context for pre-service chemistry teachers should be carried out comprehensively. This study emphasizes on the 
learning several components of PCK that provide the basis for preparing $\mathrm{CoRe}$ and $\mathrm{PaP}$ eRs chemistry topics for vocational context. The training of PCK begins from the mastery of knowledge of chemistry curriculum and vocational curriculum, developing the ability to analyze the chemistry content suitable to vocational context, the strengthening of until knowledge application in the development of the representation of the content. It became the foundation for developing a chemistry learning that is in accordance with vocational context. This article will specifically examine the effectiveness of training PCK development in increasing the self- efficacy of pre-service

\section{Research Method}

\section{Reseach Design}

The research design used is pretest-posttest control group design. The subject of the research is 36 students in the experiment class and 23 students in the control class. The research was conducted on the subject of Chemistry Vocational School on the Odd Semester of the academic year of 2014/2015 at Chemistry Education Programs of Yogyakarta State University, Indonesia

\section{Setting of Learning}

Learning in the experiment class implemented the training PCK development in five stages. The first stage was a collaborative learning through small group discussions with the structured task of arranging the content of chemistry which was being taught. The second stage is a collaborative learning through small group discussions with tasks involving analysis and meaning (the selection of chemistry content in the context of vocational). The third stage is the collaborative learning through problembased learning with a well-defined problem for content of petroleum and polymer in the automotive field context. The fourth stage is the collaborative learning through small group discussions to discuss and explore the understanding of the pre service chemistry teachers about PCK. The fifth stage is the assignment for creating the chemistry CoRe and $\mathrm{PaP}-\mathrm{eRs}$ in the vocational context. Learning in the control class implements the learning strategies lectures and discussions.

\section{Research Instrument}

There is one instrument that is used namely self-efficacy questionnaire. The instrument is used to reveal confidence of preservice chemistry teachers to their ability in teaching chemistry at vocational schools. Selfefficacy questionnaire in this study was developed based on the elaboration and adaptation from The Science Teaching Efficacy Belief Instrument-Preservice (STEBI-B) that developed by Riggs \& Knochs (1990) and reexamine by Bleicher (2004). The statements of the instrument are developed appropriate of teaching in vocational context and then translated in Indonesian. There are two dimensions of self-efficacy were examined in this study. The first dimension is Personal Science Teaching Efficacy Belief (PSTE) which refers to the confidence of pre-service chemistry teachers that what they did in the teaching of science will have good results. The second dimension is Science Teaching Outcome Expectancy (STOE) which refers to the belief of pre-service chemistry teachers that they can show his ability in teaching science successfully.

Validation of instrument is done in two stages, namely the validation of theoretical and empirical validation. First, theoretical validation results with expert judgment analyzed by content validity ratio (CVR) Lawshe for each item in the questionnaire (Wilson et al, 2012) with the formula:

$$
\text { CVR }=\frac{\mathrm{n}_{\mathrm{z}}-\mathrm{N} / 2}{\mathrm{~N} / 2}
$$

Wherein ne indicates the number of experts who agreed and $\mathrm{N}$ refers to the number of experts who validate. CVR value of calculation results are then compared with the value of the CVR table of Wilson at the significance level of $5 \%(\alpha=0,05)$. value of CVR table for the seven validators is 0,622 validator (Wilson et.al., 2012). The validation result showed that all the experts express consent of all items (24) in the questionnaire item. Therefore, all of the items in the questionnaire have a CVR value equal 1 so that it can be said valid theoretically.

The second stage is empirical validation. Self-efficacy questionnaire tested on students of Chemistry Education programs with specific criteria. Such criteria are include ever to take subject that study the chemistry learning in a vocational school or had experience teaching at vocational schools. Based on the results of empirical validation it appears that there are three items in PSTE dimensional and one item in STOE dimensional item which has a correlation value of less than 0,3 . The fourth item (numbers 1,7,10 and 16) subsequently 
excluded from the analysis of reliability. Summary results of the reliability analysis are presented in Table 1. The analysis results showed that reliability of self-efficacy questionnaire for both of dimension as well as a whole fulfill the criteria of reliable. Thus the self-efficacy questionnaire is said valid and reliable so that it can be used for data collection of research. The questionnaire is used for data collection consisted of 10 items each for dimensions PSTE and STOE. The statements in questionnaire of self-efficacy can be seen in the appendix.

Table 1. Summary of The Reliability Analysis Result

\begin{tabular}{cccc}
\hline $\begin{array}{c}\text { Self- } \\
\text { efficacy } \\
\text { dimensio } \\
\text { n }\end{array}$ & $\begin{array}{c}\text { Sum } \\
\text { of item }\end{array}$ & $\begin{array}{c}\text { alpha } \\
\text { cronbach's } \\
\text { correlation }\end{array}$ & $\begin{array}{l}\text { Reliabilit } \\
\text { y criteria }\end{array}$ \\
\hline PSTE & 10 & 0,826 & Reliable \\
STOE & 10 & 0,771 & Reliable \\
Overall & 20 & 0,886 & Reliable \\
\hline
\end{tabular}

\section{Data Analysis Technique}

Analysis of this data aims to see the extent to which an increase in self-efficacy of a pre-service chemistry teachers before and after participating in learning to develop PCK. Data is obtained from the answer choices of confidence level of pre-service teachers in selfefficacy questionnaire. The first step is do the data scoring. Scoring for each alternative answer is 5,4,3,2,1 respectively for a very sure, sure, hesitant, unsure and very unsure. The first data analysis technique used in this research was differences analysis. Self-efficacy data were analyzed by paired samples t-test. Furthermore, analysis of n-gain normalized is done to determine the extent of the increase in understanding of pre-service teachers, by the formula as follow:

$$
<g>=\frac{\text { posttest score }- \text { pretest score }}{\text { maximum score }- \text { pretest score }}
$$

\section{Finding and Discussion}

Self-efficacy in this study was measured by questionnaire which are given before and after the implementation of learning to develop PCK. Table 2 presents the results of the analysis of differences in self-efficacy scores of pre-service chemistry teachers before and after learning. The results of difference test analysis show that the significance of $t$ - test results was
0,002 . Thus, we can conclude that the null hypothesis is rejected, which means that there is a difference between mean of self-efficacy scores between before and after learning. The mean final score was higher than the initial score which indicates an increase in selfefficacy pre-service chemistry teachers.

Table 2.Self-Efficacy Scores Pre and Post Learning

\begin{tabular}{lccccc}
\hline & Mean & SD & $\mathrm{t}$ & $\mathrm{p}$ & conslusion \\
\hline Pre & 73,00 & 5,97 & $-3,420$ & 0,002 & difference \\
Post & 77,61 & 7,46 & & & \\
\hline
\end{tabular}

n-gain analysis done to see the extent of the increase in self-efficacy occurred. Mean of $\mathrm{n}$-gain obtained amounted to 0,153. n-gain values that obtained are included in the criteria of a low increase, which means that in general self-efficacy pre-service chemistry teacher slightly increased after the learning to develop PCK. The highest score before learning is 88 (out of a maximum score of 100), while the lowest score is 62. After the learning, the highest score reached on 95 (obtained by preservice chemistry teachers with the highest initial scores) and the lowest score even lower than before the learning, amounted 61 .

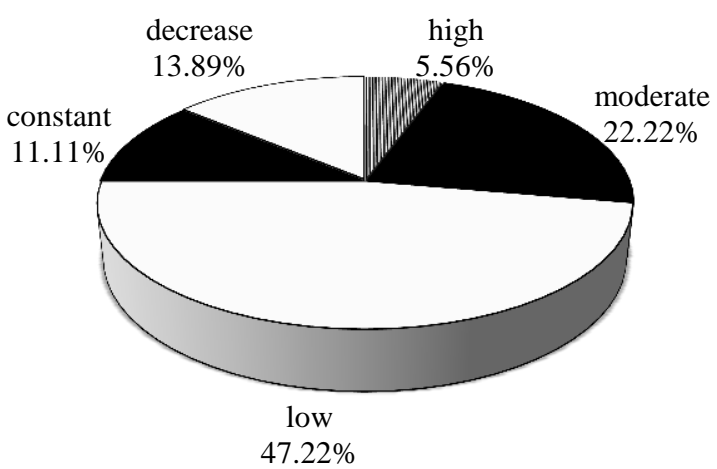

Figure 1.The distribution of criterion in n-gain change

According in n-gain criteria (Figure 1), as many as 17 pre-service teachers $(47,22 \%)$ experienced an increase in self-efficacy in the low criteria, eight $(22,22 \%)$ in the moderate criteria and only two pre-service teachers $(5,56 \%)$ who have high enhancement in selfefficacy. In addition, there are four $(11,11 \%)$ pre-service chemistry teachers who did not experience an increase in self-efficacy before and after learning. This means that the learning that followed did not affect the confidence of the four prospective teachers to teach chemistry well in vocational school. One thing to note from the results obtained, there was self- 
efficacy of pre-service chemistry teacher that decreased after following the learning to develop PCK. A total of five $(13,89 \%)$ preservice chemistry teachers have a negative $n$ gain that mean the score of self-efficacy after learning is lower than the scores before learning.

Learning to develop PCK able to increase the self-efficacy of pre-service chemistry teachers to teach in vocational school effectively. Most of prospective teachers have a good self-efficacy, which is expected later can become chemistry teachers are professional and have an impact on increasing the interest and understanding of vocational students in studying of chemistry. Self-efficacy is not something inborn or the permanent quality of an individual. Thus, a teacher self-efficacy can be grown, improved or even decreases every time. The development of pre-service chemistry teachers self-efficacy began from the process of teacher education, when teachers work until near the time of retirement. A good condition self-efficacy of pre-service chemistry teachers must continue to be nurtured in order to stay awake.

The first finding is presence of the preservice chemistry teachers with the criteria of high self-efficacy enhancement, did not experience an increase in self-efficacy, and some have self-efficacy actually decreased after attending a briefing. Depth analysis and interviews were conducted to explore further on matters that affect this circumstances. The results of interviews with the two pre-service chemistry teacher who have increased selfefficacy with high criteria indicate some facts. First, both the pre-service chemistry teachers including students who have very good mastery of curriculum content and the chemistry content in vocational context and they always active when collaborating in the group. Both also feel comfortable working in a group.

In addition, one of the pre-service chemistry teacher explain that are increasingly challenged to teach at vocational schools because it was not as easy as what was previously imagined. Factors of mastery of content affect the conviction of a pre-service teacher to be able to work well in teaching chemistry at vocational schools. Previous research supports the results of this study, which concludes that the mastering of the science content to be taught is the main source that affected the self-efficacy of pre-service science teachers (Palmer, 2006; Alkan \&
Erdem, 2014). Meanwhile, other studies revealed that knowledge of the specific chemistry content to a particular field increasing the self-efficacy of pre-service teachers to teach chemistry (Capa et.al., 2005; Alkan \& Erdem, 2012). On the other hand, the challenged attitude one of pre-service teachers who have been described previously indicated that the factor of one's feelings affect the person's level of self-efficacy. This fact is supported by the results of previous studies. The study found that the growth of positive feelings towards what should be done will affect the self-efficacy of pre-service teachers for be able to show his ability in teaching (Pendergast, Garvis \& Keogh, 2011: 50-55).

Another thing revealed from interviews with pre-service teachers who did not experience an increase in self-efficacy after following the learning to PCK development. pre-service chemistry teacher stated that belief to be able to teach chemistry effectively in vocational schools solely because it was regarded as something reasonable. The point is to teach at vocational schools had been a consequence of all pre-service teachers, and it has been realized from the beginning so is not worrying about the difficulties that may be encountered. But there is one pre-service teacher stating initially doubt his ability to linking the chemistry content to the context of vocational learning. Doubts began to disappear after knowing more of what should be mastered.

The final analysis be conducted for preservice chemistry teachers with decreased selfefficacy. The things revealed are doubts after following the learning. This is in sourced to the limitations pre-service teacher's knowledge about content in various vocational skills program at school and feel less mastering in content application knowledge. Other matters related to the heavy load that is perceived as a chemistry teacher at the vocational school. It is because the chemistry teacher should increase students' motivation in vocational schools and teach of chemistry content in accordance with the needs of vocational students. Previous research has also revealed that the reception or perception that the teacher's task is complex and difficult affecting pre-service teachers' selfefficacy (Pendergast, Garvis \& Keogh, 2011: 50-55).

Another analysis results are shown in Figure 2 which shows the distribution of n-gain 
criteria in two-dimensional self-efficacy. In the first dimension (PSTE), majority of pre-service teachers as many as 15 people $(41,67 \%)$ had a low increase. The second largest $(30,51 \%)$ had moderate increasing criteria. Each of the five pre-service chemistry teachers $(13,89 \%)$ is not increasing and decreasing their confidence in dimension PSTE. None of the preservicechemistry teachers who have an increased ngain with high criteria in this dimension.

\section{$\triangle$ PSTE $\square$ STO}

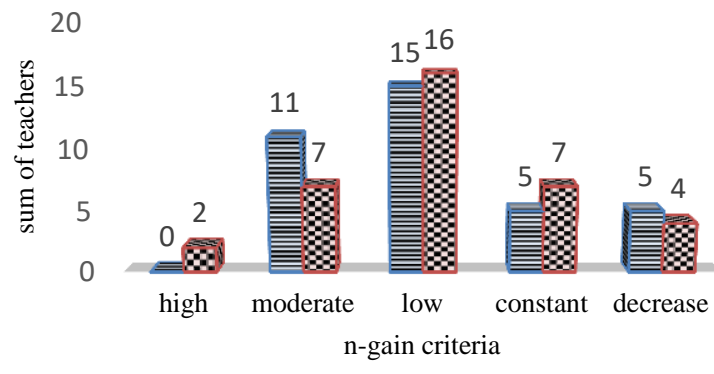

Figure 2. The distribution of n-gain criteria in two-dimensional self-efficacy

In the second dimension (STOE), the majority of pre-service chemistry teachers as many as 16 people $(44.44 \%)$ also had a low increase criteria. Meanwhile, the number of pre-service chemistry teachers who have criteria for this dimension less (only seven) than in PSTE dimension. However, in the STOE dimension there are two pre-service chemistry teachers $(5,56 \%)$ which increased with high criteria. The last, seven pre-service chemistry teachers $(19,44 \%)$ did not experience an increase in n-gain and four pre-service teachers $(11,11 \%)$ are decreasing in STOE dimension.

Two of the factors that affect selfefficacy are the knowledge and experience. Therefore, pre-service chemistry teachers should be facilitated continually to improve the chemistry understanding as well as broaden their experience in the world of vocational schools. PCK development activities that followed by pre-service chemistry teachers integrating various methods and learning content, so that is comprehensive and practical. Comprehensive because it starts from the analysis of chemistry content standard, the analysis of the chemistry content of vocational context, and the enrichment of the chemistry content in vocational context to prepare a document for designing of chemistry learning. Learning to PCK development provide basic knowledge of chemistry curriculum and chemistry content to be taught in vocational schools so that increased confidence pre-service teachers. Constructing $\mathrm{CoRe}$ and PaP-eRs chemistry in vocational context develop insights of pre-service chemistry teachers in designing learning chemistry in vocational schools effectively. These results are consistent with previous research which states that the development of PCK increase self-efficacy preservice chemistry teachers in teaching chemistry (Blonder et.al, 2013: 269).

Practical learning is providing experience for prospective teachers to develop their ability to teach in vocational school effectively. That is because the science learning experiences are the main things that have a significant impact on the confidence of preservice chemistry teachers what they did in the teaching of science will have good results (Hechter, 2010). Direct experience in understanding of the curriculum documents play an important role for pre-service chemistry teachers to understand the characteristics of the curriculum in vocational schools. This provides the rationale for the importance of pre-service chemistry teachers to involve a vocational context in preparing an effective chemistry learning at a vocational school. It gives motivation for the pre-service chemistry teachers that teaching chemistry at vocational schools should be based on the differences of chemistry learning purposes at general and vocational schools. The development of chemistry learning in vocational contexts would improve the meaningfulness of learning for vocational students.

On the other hand, collaborative learning is applied in practice the development of PCK provides the opportunity for the pre service teachers to think about themselves, compares theirs to the others', conducts a small research project, investigates the subject materials among the students, and to practice the use of high-level thinking skills. Collaborative learning encourage pre-service teachers to face the logic of their own ideas, beliefs and accuracy of preliminary understanding, and to construct their knowledge (Nagata, K. \& Ronkowski, S., 1998; Barkley dkk, 2005, Warfa, 2014). PCK development strategy in this research emphasis on activity and familiarize pre-service chemistry teachers to build learning communities that have an impact on the increasing of their self-efficacy. This is similar to the results of research Gado et.al. (2008) that examines the increase in 
aspects of science process skills and selfefficacy beginner chemistry teacher at the high school after following the professional development programs through collaborative learning.

Self-efficacy of pre-service chemistry teachers should be improved in order to carry out the learning of chemistry at a vocational school effectively. This is because self-efficacy indicates how strong a person's belief that they have the skills to do something, they sure that with the other factors will make them successful. Teachers with high self-efficacy also are more open to new ideas, more willing to adopt innovations, are less likely to experience burn-out, support pupils' autonomy to a greater extent, and are more attentive to low ability students (Brouwers \& Tomic, 2003; Henson, 2001; Ross \& Bruce, 2007). Finally, teachers with high self-efficacy exhibit greater enthusiasm for teaching, have greater commitment for teaching, and are more likely to remain in the teaching profession (Tschannen-Moran \& Hoy, 2001: 789).

Thus, high self-efficacy influences the mindset of pre-service teachers about their ability to complete the task as a professional chemistry teacher at a vocational school. Preservice chemistry teachers with high selfefficacy tend to run something when they feels competent and confident. They were able to determine how much effort it does to survive and the flexibility to address the problem in order to survive the unfavorable situation. The same thing was revealed in the research of Gavora (2010:17). It found that low selfefficacy hinder the professional development of teachers. In addition, high self-efficacy of preservice teachers in teaching chemistry at vocational school, not only benefit from the dimensions of their course (PSTE) but is also beneficial for STOE dimension. This dimension relates to the increase in performance later as a teacher who is able to deliver the success of their students. Calik (2013: 223) had studied that the use of technology can improve the teacher's self-efficacy. The use of technology can increase the student's interest and make the learning process better. Thus, preservice teacher's self-efficacy can be improved by given experience to conduct ICT based chemistry learning.

\section{Conclusion}

The strategy for PCK development of chemistry in vocational context capable to improve self-efficacy of pre-service chemistry teachers to teach in vocational school effectively. In general, pre-service chemistry teachers' self-efficacy increasing after attending learning for the development of PCK. The increasing occurred with low criteria. However, there are five pre-service chemistry teachers which has self-efficacy dropped after following study. The four other pre-service teachers are not experienced an increase or decrease in their self-efficacy. Good conditions of self-efficacy is a great asset and gives hope to realize professional chemistry teacher at vocational schools. The main implication of this research is the need for restructuring of the curriculum for pre-service chemistry teacher education programs that are more concerned with professional development in the context of vocational schools.

\section{References}

Alkan, F. \& Erdem, E. (2012). The relationship between teacher self-efficacy and competency perceptions of chemistry teacher candidates, Procedia-Social and Behavioral Sciences, 47, 1927-1932.

Alkan, F. \& Erdem, E. (2014). The relationship between metacognitive awareness, teacher self-efficacy and chemistry competency perceptions, Procedia Social and Behavioral Sciences, 143, 778 -783 .

Bandura, A. (1997). Self-Efficacy: The Exercise of Control. New York: W.H. Freeman and Company.

Barkley, E.F., Cross, K.P. \& Major. C.H. (2005). Collaborative Learning Techniques. San Fransisco: Jossey-Bass.

Bleicher, R. E. (2004). Revisiting the stebi-b: measuring self-efficacy in preservice elementary teachers, School Science and Mathematics, 108 (8), 383- 391.

Bleicher, R. E., \& Lindgren, J. (2005). Success in learning science and preservice science teaching selfefficacy, Journal of Science Teacher Education, 16, 205-225.

Blonder, R., Jonatan, M., Dov, Z.B., Benny, N., Rap, S. \& Sakhnini, S. (2013). Can you tube it? providing chemistry teachers with technological tools and enhancing their self-efficacy beliefs, Chemical Education Research and Practicet, 14, 269-285. 
Brouwers, A., \&Tomic, W. (2003). A test of the factorial validity of the Teacher Efficacy Scale, Research in Education, 69, 67-79.

Bucat R., (2004), Pedagogical content knowledge as a way forward: Applied research in chemistry education, Chemical Education Research and Practice, 5, 215-228.

Calik, M. (2013). Effect of technologyembedded scientific inquiry on senior science student teachers' self-efficacy. Eurasia Journal of Mathematics, Science \& Technology Education, 9(3), 223-232.

Cantrell, P., Young, S., \& Moore, A. (2003). Factors affecting science teaching efficacy of preservice elementary teachers, Journal of Science Teacher Education, 14, 177-192.

Çapa, Y., Çakiroğlu, J., \& Sarikaya, H. (2005). The development and validation of a Turkish version of teachers' sense of efficacy scale, Education and Science, 30(137), 74-84.

Dolfing, R., Bulte, Astrid M.W., Pilot, A. \& Vermunt, J.D. (2011). Domain-spesific expertise of chemistry teachers on context-based education about macromicro thingking in structure-property relations, Research of Science Education, DO1. 10. 1007/s11165-0119211-z. open access at Springerlink.com, 22 Maret 2011.

Faraday, S., Overton, C., \& Cooper, S. (2011). Effective Teaching and Learning in Vocational Education. London: LSN. http://policyconsortium.co.uk/wpcontent/uploads/2012/01/110052RP effe ctive-VET final-report1.pdf

Finch, C. dan Crunkilton, J.R. (1984). Curriculum Development in Vocational and Technical Education: Planning,Content and Implementation. Boston : Allyn and Bacon, Inc.

Gado, I.,Verma, G. \& Simonis, D. (2008). Middle grade teachers' perceptions of their chemistry teaching efficacy: findings of a one year long professional development program, Georgia Educational Researcher, 6 (1), 46-57.

Gavora, P. (2010). Slovak pre-service teacher self-efficacy: theoretical and research considerations, The New Educational Review, 21(2), 17-30.

Gess-Newsome J (1999) Pedagogical content knowledge: an introduction and orientation. In: Gess-Newsome J,
Nederman NG(eds) Examining pedagogical content knowledge. Kluwer, Dordrecht, 3-17.

Henson, R. (2001). Teacher self-efficacy: Substantive implications and measurement dilem-mas. Paper at the annual meeting of the Educational Research Exchange. January 26, 2001. Texas A\&M University, Texas. www.des.emory.edu/mfp/erekeynote.pdf (retrieved Nov. 9., 2007).

Hechter, R.P. (2011). Changes in preservice elementary teachers' personal science teaching efficacy and science teaching outcome expectancies: the influence of context, Journal of Science Teacher Education, 22 (2), 187-202.

Hume, A. \& Berry, A. (2011). Constructing cores - a strategy for building pck in preservice science teacher education, Research in Science Education, 41, 341355.

Kapyla, M., Heikkenen, JP. \& Asunta, T. (2009). Influence of content knowledge on pedagogical content knowledge: the case teaching photosynthesis and plant growth, International Journal of Science Education, 31(10), 1395-1415.

Khasawneh, S.A., Olimat, Q., \& Abu, T. (2008). Measuring the perceptions of vocational education students regarding the application of national vocational teacher standard in the classrooms: the key to human resource education in jordan. IJAES, 2(1), 24-37

Loughran, J., Berry, A., \& Mulhall, P. (2008). Understanding and Developing Science Teachers' Pedagogical Content Knowledge. Rotterdam: Sense Publishers.

Loughran, J., Mulhall, P., \& Berry, A. (2008). Exploring pedagogical content knowledge in science teacher education, International Journal of Science Education, 30 (10), 1301-1320.

Magnusson, S., Krajcik, J., \& Borko, H. (1999). Nature, Source and Development of Pedagogical Content Knowledge. In J. Gress-Newsome \& N.G Lederman (Eds.), Examining Pedagogical Content Knowledge (hlm. 95-132). Dordrecht, Netherland: Kluwer.

Nagata, K. \& Ronkowski, S. (1998). Collaborative Learning: Differences Between Collaborative and Cooperative Learning.. The Office of Instructional 
Consultation, University of California Santa Barbara. http://www.oic.id.ucsb.edu/Resources/Co llab-L/Differences.html, $\quad[4$ Januari 2006).

Palmer, D.H. (2006). Sources of self-efficacy in a science methods course for primary teacher education students. Research in Science Education, 36, 337-353.

Pendergast, D., Garvis, S. \& Keogh, J. (2011). Pre-service student-teacher self-efficacy belirfs: an insight into making of teachers, Australian Journal of Teacher Education, 36 (12), 46-58.

Riggs, I. dan Knochs, L. (1990). Toward the development of an elementary teacher's science teaching efficacy belief instrument, Science Education, 74, 625637.

Rohaan, E.J, Taconis, R., \& Jochems, W.M.G. (2009). Measuring teachers' pedagogical content knowledge in primary technology education, Research in Science \&Technological Education, 27(3), 27338.

Ross, J., \& Bruce, C. (2007). Professional development effects on teacher efficacy: Results of randomised field trial, The Journal of Educational Research, 101 (1), 50-60.

Schoon, K. J., \& Boone, W. J. (1998). Selfefficacy and alternative conceptions of science of preservice elementary teachers. Science Education, 82(5), 553569

Shulman, L.S. (1986). Who understand: knowledge growth in teaching, Educational Researcher, 15(2), 4-14.
Shulman, L.S. (1987). Knowledge and teaching of new reform. Harvard Educational review, 57, 1-22.

Shulman, L.S. (1987). Knowledge and teaching of new reform. Harvard Educational review, 57, 1-22.

Tschannen-Moran, M., \& Hoy, A.W. (2001). Teacher efficacy: Capturing an elusive construct, Teaching and Teacher Education, 17, 783-805.

Wilson, R.F., Pan, Wei \& Schumsky. (2012). Recalculating of the critical values for lawshe's content validity ratio, Measurement and Evaluation in Counseling and Development, 45(3), 197-210.

Warfa, A.R., Roehrig, G., Schneiderc, J., \& Nyachwayad. (2014). Collaborative discourse and the modeling of solution chemistry with magnetic 3D physical models - impact and characterization, Chemistry Education Research and Practice, 15, 835-848.

Woolfolk, A. (2008). Educational Psychology. Active Learning Edition. Boston: Allyn and Bacon.

Yilmaz-Tuzun, O. \& Topcu, M. S. (2008). Relationships among preservice science teachers' epistemological beliefs, epistemological world views, and selfefficacy beliefs. International Journal of Science Education, 30(1), 65 - 85.

Zimmerman , B.J. (2000). Self efficacy: an essential motive to learn. in self efficacy beliefs, Contemporary Educational Psychology, 25, 82-91. 